Olesen, O. B. \& Braithwaite, R. J. 1982: Glaciological investigations at Qamanârssûp sermia, West Greenland. Rapp. Grønlands geol. Unders. 110, 88-90.

\title{
Photogrammetric investigations at glaciers in West Greenland
}

\section{N. Tris Knudsen}

In order to determine glacier variations, photogrammetric measurements and especially terrestrial photogrammetric surveys have become increasingly important because they can be carried out accurately and quickly. As part of the GGU programme for regional mapping of the hydroelectric potential of glaciers in West Greenland, a photogrammetric survey was carried out at Qamanârssûp sermia in 1980 and in Johan Dahl Land in 1982. The survey was carried out by staff members from the Geological Institute, Aarhus University.

\section{Qamanârssûp sermia}

The main result of the survey was the construction of three maps on the scale of 1:10000 covering Qamanârssûp sermia below $900 \mathrm{~m}$ above sea level and the neighbouring glacier to the north $1 \mathrm{CH} 21001$ below $600 \mathrm{~m}$ above sea level. They are based on vertical aerial photographs taken on 28th August 1968. Two maps on the same scale covering Qamanârssûp sermia below $500 \mathrm{~m}$ above sea level and $1 \mathrm{CH} 21001$ below $550 \mathrm{~m}$ above sea level were constructed using terrestrial photogrammetric measurements taken on 3rd August and 31st July, respectively. To establish a net of control points for these surveys a triangulation was carried out around the periphery of the glaciers.

Information on glacier variation is gained by comparing maps depicting the glacier surface at different times. The result of a comparison between the maps covering Qamanârssûp sermia is shown in figure 45.

It is safe to conclude that the glacier was nearly stationary between 1968 and 1980 . Right at the margin where it ends in lakes an advance was noticed, but this might just reflect a slight change in calving from one year to the next, because it is often observed that large pieces are calved rather than small bits. The lake at about $70 \mathrm{~m}$ was definitely smaller in 1980 than in 1968, probably because erosion by the stream connecting the 50 and $70 \mathrm{~m}$ lakes lowered the outlet, and also because of the influx of sediment. Between the two lakes a retreat of the order of 25 to $50 \mathrm{~m}$ could be determined. Along the periphery in general no changes could be seen; the variations were a result of the difficulty of determining the exact position of the glacier margin because of debris cover. On the surface right at the margin a slight thinning could be seen, but it was less than $10 \mathrm{~m}$ and at higher elevations the contour lines were almost identical, the differences being within the limits of experimental error. 


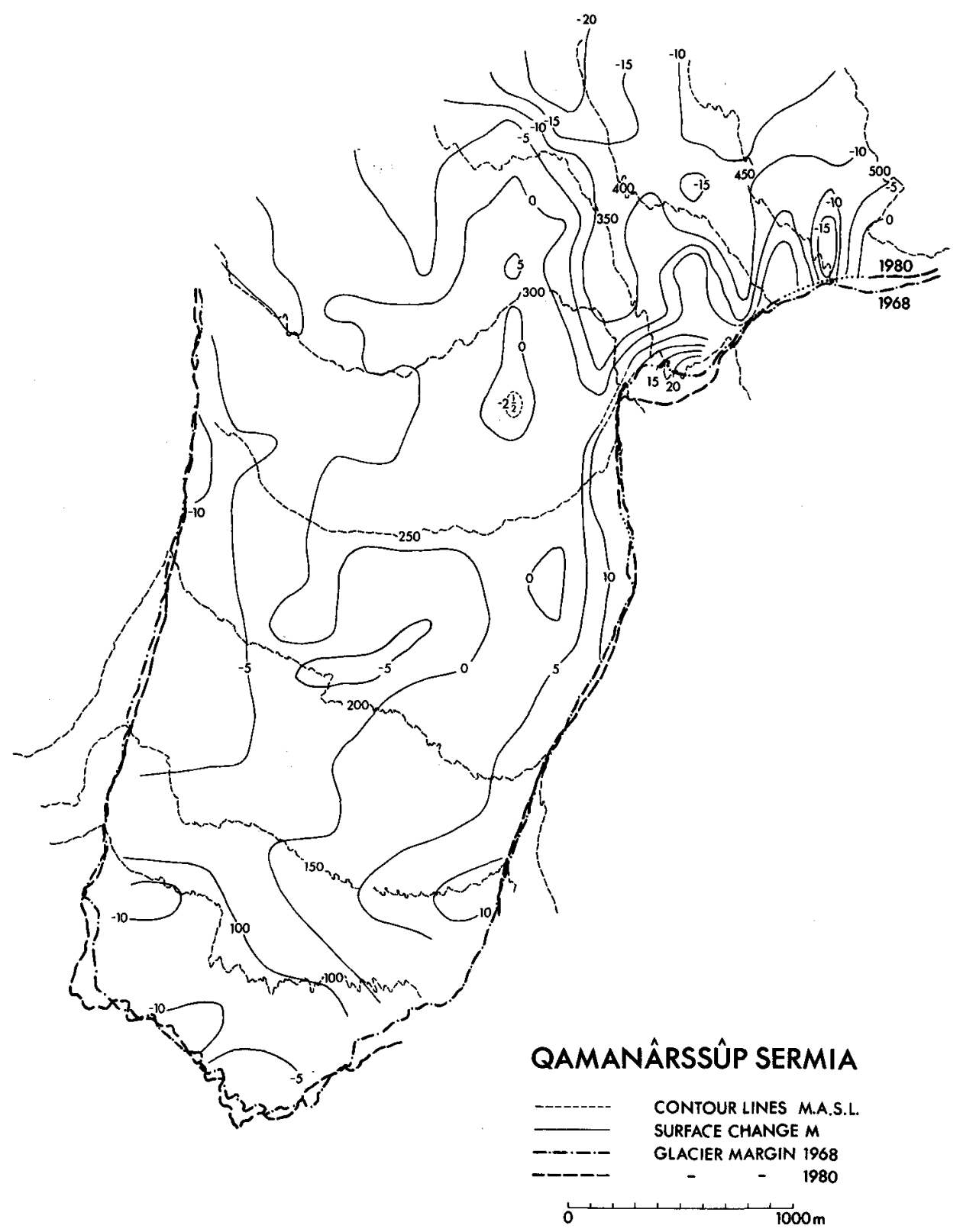

Fig. 45. Surface change at Qamanârssûp sermia $\left(64^{\circ} 29^{\prime} \mathrm{N}, 49^{\circ} 33^{\prime} \mathrm{W}\right.$ in the inner part of Godthåbsfjord) during the period 1968-1980. 


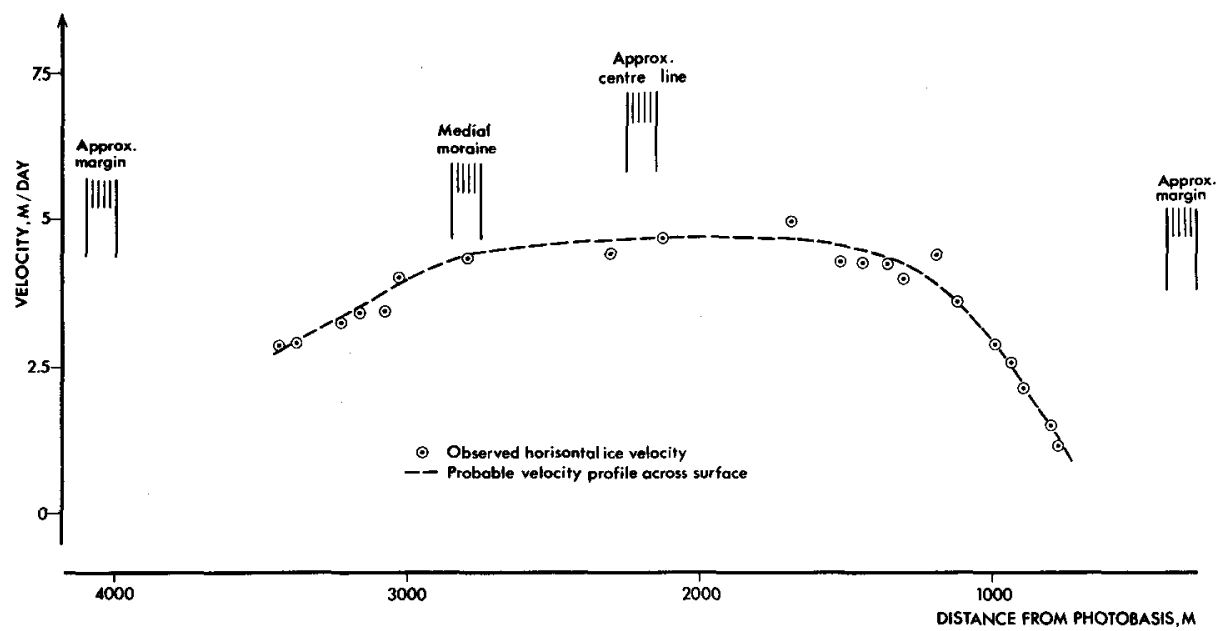

Fig. 46. Variation of horizontal ice velocity across the surface of Eqalorutsit kangigdlit sermiat (1AH08022) at about $600 \mathrm{~m}$ above sea level.

\section{John Dahl Land}

During the period 27th July to 20th August a triangulation network was established in the area around Valhaltinde covering about $50 \mathrm{~km}^{2}$. The purpose of the triangulation was to establish the horizontal and vertical control for construction of topographic maps on the scale of 1:10000 with the use of aerial photographs taken in 1953,1977, and 1981. The area covered comprises Nordbogletscher, Nordgletscher and Sydgletscher with Hullet.

Terrestrial photographs were taken from points covering the margins of Nordbogletscher, Nordgletscher, and the Hullet area with Sydgletscher. Photostations were tied in with the triangulation net by use of resection.

At Equalorutsit kangigdlit sermiat two terrestrial photogrammetric surveys were carried out at about $600 \mathrm{~m}$ above sea level, with a time interval of 89 hours. The main object was to procure data for the determination of ice velocity along a profile across the ice surface. Although conditions were difficult from a surveyor's point of view and nothing was known about the order of ice velocity, the subsequent processing of the results is most promising. Preliminary results showing the variation of horizontal ice velocity are shown in figure 46 .

On the basis of the maps constructed it is the intention to obtain quantitative data on the glacier advance observed during recent years at the margins of Nordbogletscher and Nordgletscher (Clement, 1981).

\section{Reference}

Clement, P. 1981: Glaciologiske undersøgelser i Johan Dahl Land, Vestgrønland 1980. Unpubl. intern. GGU rep., 53 pp. 